\title{
A new year and new opportunities
}

Published at www.cmaj.ca on Dec. I3, 2006.

$\mathrm{M}$ y first memorable encounter with $C M A J$ was reading the 7-part series "How to read clinical journals," which began in $198 \mathrm{I} .{ }^{1}$ This series, one of the most frequently cited ever in CMAJ, changed medical practice worldwide and played a pivotal role in my life. Following this dramatic initial impression, I wrote and reviewed for $C M A J$ many times. Until recently, my career as a clinical researcher and critical care physician was taking me in a different direction. Before this opportunity to become Editor-in-Chief of $C M A J$, I had never envisioned being a central player in Canada's premier medical journal.

In this, my first editorial, I give my reasons for becoming Editor-in-Chief. Over the past several months, I came to know and admire the professionalism and devotion of CMAF's staff. Despite being without a permanent editor for over 8 months, they demonstrated grace under pressure. With their help, Acting Editor-in-Chief Noni MacDonald and her interim editorial board were able to build on the foundation of the former Editor-in-Chief, John Hoey, and his editorial team, who brought $C M A J$ to a respected position on the international stage. For this strong foundation, they deserve our gratitude and acknowledgement.

Before I accepted the position of Editor-in-Chief, I had extensive discussions with the CMA, its Board of Directors and the Journal Oversight Committee about my ideas for the journal and about our mutual roles and responsibilities. These discussions provided a sound basis for mutual respect and trust going forward. I am convinced that they are committed to my vision for $C M A J$ and, more particularly, to the journal having an independent voice. Thanks to the framework outlined in the CMAJ Governance Review Panel's report (www.cmaj.ca /pdfs/GovernanceReviewPanel.pdf), we have one of the clearest rules of engagement and responsibility of any medical journal.

CMAF's team and I believe there are exciting opportunities for the journal in the years ahead. We aim to substantially increase both the quality and quantity of original patientcentred research articles in the journal. Without a doubt, there is plenty of high-quality clinical and health services research being conducted in Canada and elsewhere to strengthen $C M A$ F's scientific content. The challenge we are prepared to take on will be to convince Canada's academic community to support this vision and submit some of its highest quality manuscripts to the journal. In exchange, we plan to increase the assistance provided to prospective authors as well as expedite the review and acceptance processes where possible. We will also find ways to better profile work submitted to the journal, for example, by having more themerelated issues, by increasing the number of commentaries on important original contributions and by enhancing the journal's electronic version. We will ensure that researchers' work is not only disseminated but has an impact on clinical practice. Greater use of the Web will assist in the dissemination of decision support and audit tools that will help physicians in daily practice. To better represent the varied interests and communities of the more than 60 ooo physicians who receive $C M A J$, we will broaden the representation on the editorial board. In addition, we will seek different ways to discuss common clinical issues facing family physicians, specialists and other health care professionals. We also plan to increase the journal's content for our French-speaking readers.

Our Canadian health care system is experiencing a number of challenges. There often exist divergent interpretations of the issues and their solutions. Because informed debate on controversial issues is a cornerstone of a great medical journal, $C M A J$ will continue to provide a forum for discussion of issues such as the funding of the health care system and wait times, but we will seek ways to enhance the quality of the discourse published in the journal. Debates about health services and public policy require a well-described frame of reference and perspective, clear definitions, a solid basis in evidence (or recognition of the need to acquire it if none exists) and a clear description of ideologies, beliefs and values underpinning the decision-making processes. $C M A J$ will endeavour to provide a platform for innovative and, yes, controversial ideas. However, all editorials will be signed to ensure that we accurately attribute views to the author(s) and not the CMAJ or the CMA.

I invite feedback from you, our readers, as we explore novel approaches in our electronic and print formats of the journal. I and members of $C M A$ Fs editorial board and staff will be visiting various parts of the country to directly engage you. This is your journal. Help us build on its foundation, for your benefit.

\section{Paul C. Hébert}

Editor-in-Chief

\section{REFERENCE}

I. Department of Clinical Epidemiology and Biostatistics, McMaster University Health Sciences Centre. How to read clinical journals: I. Why to read them and how to start reading them critically. CMAJ I98I;I24(5):555-8. 